\title{
Video Article \\ Detection and Recovery of Palladium, Gold and Cobalt Metals from the Urban Mine Using Novel Sensors/Adsorbents Designated with Nanoscale Wagon- wheel-shaped Pores
}

\author{
Sherif A. El-Safty ${ }^{1,2}$, Mohamed A. Shenashen ${ }^{1}$, Masaru Sakai ${ }^{3}$, Emad Elshehy ${ }^{1}$, Kohmei Halada ${ }^{1}$ \\ ${ }^{1}$ National Institute for Materials Science, Japan \\ ${ }^{2}$ Graduate School for Advanced Science and Engineering, Waseda University \\ ${ }^{3}$ Center for Research in Isotopes and Environmental Dynamics, Tsukuba University
}

Correspondence to: Sherif A. El-Safty at sherif.elsafty@nims.go.jp; sherif@aoni.waseda.jp

URL: https://www.jove.com/video/53044

DOI: doi:10.3791/53044

Keywords: Engineering, Issue 106, Nanoscale scaffolds, wagon-wheel-shaped, sensor/adsorbent, detection, recovery, palladium, gold and cobalt metals, urban mine

Date Published: $12 / 6 / 2015$

Citation: El-Safty, S.A., Shenashen, M.A., Sakai, M., Elshehy, E., Halada, K. Detection and Recovery of Palladium, Gold and Cobalt Metals from the Urban Mine Using Novel Sensors/Adsorbents Designated with Nanoscale Wagon-wheel-shaped Pores. J. Vis. Exp. (106), e53044, doi:10.3791/53044 (2015)

\section{Abstract}

Developing low-cost, efficient processes for recovering and recycling palladium, gold and cobalt metals from urban mine remains a significant challenge in industrialized countries. Here, the development of optical mesosensors/adsorbents (MSAs) for efficient recognition and selective recovery of $\mathrm{Pd}(\mathrm{II}), \mathrm{Au}(\mathrm{III})$, and $\mathrm{Co}(\mathrm{II})$ from urban mine was achieved. A simple, general method for preparing MSAs based on using high-order mesoporous monolithic scaffolds was described. Hierarchical cubic la3d wagon-wheel-shaped MSAs were fabricated by anchoring chelating agents (colorants) into three-dimensional pores and micrometric particle surfaces of the mesoporous monolithic scaffolds. Findings show, for the first time, evidence of controlled optical recognition of $\mathrm{Pd}(\mathrm{II}), \mathrm{Au}(\mathrm{III})$, and $\mathrm{Co}(\mathrm{II})$ ions and a highly selective system for recovery of $\mathrm{Pd}(\mathrm{II})$ ions (up to $\sim 95 \%$ ) in ores and industrial wastes. Furthermore, the controlled assessment processes described herein involve evaluation of intrinsic properties (e.g., visual signal change, long-term stability, adsorption efficiency, extraordinary sensitivity, selectivity, and reusability); thus, expensive, sophisticated instruments are not required. Results show evidence that MSAs will attract worldwide attention as a promising technological means of recovering and recycling palladium, gold and cobalt metals.

\section{Video Link}

The video component of this article can be found at https://www.jove.com/video/53044/

\section{Introduction}

Driving forces for the booming use of platinum group metals (PGM) are their extraordinary and sometimes exclusive properties, which make them essential components in a broad range of applications. PGMs can play a part in building a sustainable society, and these materials are used in a variety of contemporary applications and products: chemical process catalysis, automotive emissions control, information technology, consumer electronics, fine jewelry, preparation of dental materials, photovoltaic fuel cells, and lithium ion batteries (LIB) ${ }^{1-10}$. Over the past century, worldwide economic changes have been powered by the use of PGMs. Because of the importance of PGMs in clean technologies and high-technology equipment, the use of PGMs has increased dramatically in modern society. Because of the sharp increases in the use of PGMs, particularly in the production of electronic equipment, the accumulation of electronic waste (e-waste) has led to environmental challenges and concerns. Moreover, the recent surge in commodity prices has generated a new interest in the mining of e-wastes ${ }^{1-4}$.

E-wastes contain both hazardous materials and valuable palladium, gold and cobalt metals. If e-wastes are disposed of in landfills or not treated in an environmentally sound manner, they may pose a high risk of environmental damage. Palladium, gold and cobalt metals in e-wastes are a sustainable and "green" secondary resource of such metals ${ }^{5-10}$. Therefore, efficient processes for recovering palladium, gold and cobalt metals from e-wastes are urgently needed.

Future advancements in many technological fields will require control of primary metal resources. Because of the growing importance of palladium, gold and cobalt metals in industrial applications and solutions to environmental problems ${ }^{11-13}$, developing adsorption/extraction techniques for the recognition and recovery of such metals has become a top priority.

The main precious metals used in electronic products are silver, gold, palladium, platinum, and small quantities of rhodium ${ }^{4-8}$. Recovering palladium and gold has become crucial because of their unique combination of properties in a wide range of industrial applications, economic value, and rare occurrence. Market mechanisms have been influential in increasing the rates of collection and recycling of circuit boards of outdated PCs, TVs, mobile phones, and other electronic devices. Mass-produced consumer components, such as computer motherboards, contain approximately $80 \mathrm{~g}$ of $\mathrm{Pd}$ and $300 \mathrm{~g}$ of Au per ton of e-waste; the corresponding amounts for mobile phone handsets are $130 \mathrm{~g}$ of Pd and 
$200 \mathrm{~g}$ of Au per ton of e-waste ${ }^{5-10}$. This urban mine holds immense amounts of these metals (by comparison, Au and Pd are present in extremely low concentrations in rocks $(\sim 4 \mathrm{ng} / \mathrm{g})$, soils $(1 \mathrm{ng} / \mathrm{g})$, seawater $(0.05 \mu \mathrm{g} / \mathrm{L})$, and river water $\left.(0.2 \mu \mathrm{g} / \mathrm{L})^{14-16}\right)$. To ensure a continuing and reliable supply of palladium, gold and cobalt metals for future technological innovations and new electronic equipment, it is important to develop an efficient and low-cost technology for recycling precious metals from e-waste. Such technology could serve as insurance against a future scarce availability of rare earth ores, which are predicted to be in short supply, or even exhausted, within 100 years.

An element such as cobalt has an essential input to nearly all of the electrochemical storage energy cells such as LIBs ${ }^{17-19}$. Because of the fast growth of information technology and a wide-range utilization of LIBs, the release of LIBs as e-wastes explored a new environmental challenge ${ }^{18-20}$. Therefore, handling these wastes with care by recovering these resources might open a new avenue in the environment and industrial applications.

Several powerful and well-established methodologies and analytical techniques have been used to discriminate and quantify Au(III), $\mathrm{Pd}(\mathrm{II})$, and $\mathrm{Co}(\mathrm{II})$ in natural ore and industrial waste, including flame and carbon furnace atomic absorption spectrophotometry, ultraviolet-visible (UVvis) spectrophotometry, neutron activation analysis, and inductively coupled plasma mass spectrometry ${ }^{14-16,21-27}$. Despite their versatility and growing popularity, these analytical techniques suffer from many shortcomings. For example, they usually require careful planning and testing, involve many sample preparation steps to minimize interference from the sample matrix, require sophisticated instrumentation and well-trained individuals, and must be performed under rigorous experimental conditions ${ }^{17,21}$. Moreover, all of these analytical techniques incorporate preconcentration and separation steps, such as solvent extraction, coprecipitation, ion exchange, and adsorption, to pre-concentrate the target metal ions from the matrix components prior to their determination ${ }^{20-27}$. Moreover, hydrometallurgy and pyrometallurgy techniques are commonly used in the recycle chain in industry ${ }^{19-22}$. Therefore, developing efficient, cost-effective and easy-to-use analytical methods to recover palladium, gold and cobalt metals from natural ore and industrial waste are important both for environmental protection and in the industrial sector ${ }^{11-13}$.

New technologies can offer new approaches to chemical analysis and recovery of metals from natural ore and industrial waste. Recent progress has been made in reducing the cost and shortening the time to fabricate optical chemical nanosensors/adsorbents; however, optical adsorbents are still used for specific real-world sensing, extraction, and recovery applications for a wide range of metals ${ }^{28-36}$. Recently, research has focused on tailoring specific solid mesoporous monoliths for use as highly sensitive sensors for the simple and simultaneous naked-eye detection and removal of toxic and precious metal ions, such as mercury and gold ions, from aquatic samples ${ }^{28-32}$. Here, a process for selectively detecting and efficiently recovering $\mathrm{Au}(\mathrm{III})$ and $\mathrm{Pd}(\mathrm{II})$ from the urban mine was reported; additionally, the process can be applied for the recovery of Co(II) ions from LIBs. Recycling metals by this process should not only serve as a secondary source of $\mathrm{Au}(\mathrm{III}), \mathrm{Pd}(\mathrm{II})$, and $\mathrm{Co}$ (II) ions but also reduce environmental pollution. The protocol designs of wagon-wheel-shaped MSAs show, for the first time, evidence of controlled optical recognition of $\mathrm{Au}(\mathrm{III}), \mathrm{Pd}(\mathrm{II})$, and $\mathrm{Co}(\mathrm{II})$ ions, and a highly selective system for recovery of $\mathrm{Pd}(\mathrm{II})$ ions (up to $\sim 95 \%$ ) in ores and industrial wastes.

\section{Fabrication of Wagon-wheel-shaped, Cubic la3d Mesoporous Monolithic Scaffolds}

NOTE: Control cubic geometry (preferentially gyroidal la3d symmetry) and micrometric particle surfaces of mesoporous monolithic scaffolds by using triblock copolymer Pluronic P123 [P123; poly(ethylene oxide-block-propylene oxide-block-ethylene oxide) $\left.\left(\mathrm{EO}_{20} \mathrm{PEO}_{70} \mathrm{EO}_{20}\right)\right]$ as a template.

1. Under typical conditions, add $\mathrm{P} 123$, pentadecane, and tetramethyl orthosilicate (TMOS) at a mass ratio of 1.6:2:1.2 to $\mathrm{HCl} / \mathrm{H}_{2} \mathrm{O}(\mathrm{pH} \sim 1.0)$ in a $200-\mathrm{ml}$ round-bottom flask; then shake mixture at $45^{\circ} \mathrm{C}$ until forming a homogeneous sol-gel.

2. Connect flask to a rotary evaporator, and evaporate mixture at $45^{\circ} \mathrm{C}$ and a starting pressure of $1,023 \mathrm{hPa}$. Under these conditions, exothermic hydrolysis and condensation of TMOS occur rapidly.

3. Continue evaporation of the mixture for 10-20 min to obtain the optical gel-like wagon-wheel-shaped monolith around the wall of the connect flask $^{37-39}$.

4. Dry the flask containing the as-made monolith at $45^{\circ} \mathrm{C}$ for $24 \mathrm{hr}$ to complete drying process.

5. Treat dried wagon-wheel-shaped monolith at $450^{\circ} \mathrm{C}$ for $8 \mathrm{hr}$ under normal atmospheric conditions.

6. Grind calcined solid monolith completely by using mortar and pestle, and store ground material for later use as a carrier platform in fabrication of MSAs.

\section{Characterization of Materials}

1. High-resolution transmission electron microscopy (HRTEM)

1. Disperse $1 \mathrm{mg}$ of sample in $5 \mathrm{ml}$ ethanol solution using an ultrasonic cleaner, and then drop two droplets of sample on a copper grid.

2. Vacuum-dry the grid for 20 min prior to inserting samples in HRTEM column.

3. Perform HRTEM using a transmission electron microscope connected to a CCD camera. Record HRTEM micrographs at an acceleration voltage of $200 \mathrm{kV}$ to obtain a lattice resolution of $0.1 \mathrm{~nm}$.

2. $\mathrm{N}_{2}$ adsorption-desorption isotherms

1. Pre-treat wagon-wheel-shaped samples at $100^{\circ} \mathrm{C}$ for $8 \mathrm{hr}$ under vacuum to equilibrate pressure to $10^{-3}$ Torr.

2. Measure $\mathrm{N}_{2}$ adsorption-desorption isotherms at $77 \mathrm{~K}$ using a surface area and pore size analyzer as per the manufacturer's instructions

3. Determine pore size distribution from adsorption isotherms by using nonlocal density functional theory. Calculate specific surface area $\left(S_{\mathrm{BET}}\right)$ by using multipoint adsorption data from linear segments of the $\mathrm{N}_{2}$ adsorption isotherms using Brunauer-Emmett-Teller (BET) theory.

3. Small-angle powder X-ray diffraction (XRD) 
1. Measure XRD patterns by using an 18-kW diffractometer and monochromated CuKa radiation, as per the manufacturer's instructions.

2. Record diffractions by using both a graphite monochromator and Göbel mirror detectors with $2 \theta$ angles between $0.1^{\circ}$ and $6.5^{\circ}$, corresponding to $d$-spacings between 88.2 and $1.35 \mathrm{~nm}$.

3. Grind sample and spread the powder on the sample holder. Confirm resolution of diffraction peaks with standard reproducibility in $2 \theta$ $\left( \pm 0.005^{\circ}\right)$. Repeat sample measurement three times with rotation at various angles $\left(15^{\circ}, 30^{\circ}\right.$, and $\left.45^{\circ}\right)$.

\section{Fabrication of Pd(II)-MSA-1, Au(III)-MSA-2, and Co(II)-MSA-3}

1. Synthesis of Pd(II)-MSA-1 and Co(II)-MSA-3

NOTE: Use a pressure-assisted method to direct the modification of wagon-wheel-shaped, cubic la3d monoliths by 1,5diphenylthiocarbazone dicarboxylate (L1) and 2-nitroso-1-naphthol (L3) ligands (0.1 M EtOH solutions) to fabricate Pd(II)-MSA-1 and Co(II)MSA-3, respectively.

1. Add ethanolic 1,5-diphenylthiocarbazone dicarboxylate (L1) or 2-nitroso-1-naphthol (L3) solutions to solid wagon-wheel monoliths into round flask and mix under shaking for $1 \mathrm{~min}$.

2. Connect flask containing heterogeneous $\mathrm{EtOH}-\mathrm{L} 1 /$ solid monolith mixture to a rotary evaporator, and evaporate mixture at $45{ }^{\circ} \mathrm{C}$ and a starting pressure of $1,023 \mathrm{hPa}$.

3. Connect another flask containing heterogeneous $\mathrm{EtOH}-\mathrm{L} 3 /$ solid monolith mixture to a rotary evaporator, and evaporate mixture at $50{ }^{\circ} \mathrm{C}$ and a starting pressure of $1,023 \mathrm{hPa}$. Remove $\mathrm{EtOH}$ solution from heterogeneous $\mathrm{EtOH}$-ligand/solid monolith mixture under vacuum at ambient temperature.

4. Clarify the formation mechanism of ligand-solid (MSA-1 and MSA-3) of physisorbed short-range interactions (i.e., van der Waals and Hbonding interactions) between the abundant hydroxyl groups of the active surface sites of the wagon-wheel-shaped scaffolds and the heteroatom ligands 40,41 .

5. Calculate the amounts of immobilized L1 and L3 as follows: $q_{\mathrm{e}}=\left(C_{0}-C_{\mathrm{e}}\right) \mathrm{V} / \mathrm{m}$, where $q_{\mathrm{e}}$ is adsorbed amount, $V$ is solution volume $(\mathrm{L})$, $m$ is mass of the carriers $(\mathrm{g})$, and $C_{0}$ and $C_{e}$ are initial and supernatant probe concentrations, respectively. The amount of immobilized $\mathrm{L} 1$ and $\mathrm{L} 3 \mathrm{can}$ be expected to be around $0.09 \mathrm{mmol} / \mathrm{g}$.

2. Synthesis of $\mathrm{Au}(\mathrm{III})-\mathrm{MSA}-2$

NOTE: Apply building blocks protocol to synthesize Au(III)-MSA-2:

1. Immobilize a $40 \mathrm{ml}$ of $0.1 \mathrm{M}$ ethanol solution of dilauryldimethylammonium bromide (DDAB) into $0.5 \mathrm{~g}$ of wagon-wheel-shaped $\mathrm{HOM}$ scaffolds using a rotary evaporator to produce wagon-wheel-shaped HOM-DDAB monoliths.

2. Dissolve $20 \mathrm{mg}$ of hydrophilic6-hydroxy-5-(4-sulfonatophenylazo)-2-naphthalenesulfonic acid disodium salt (L2) ligand in $80 \mathrm{ml}$ of D.I. water. Add $0.5 \mathrm{~g}$ of solid HOM-DDAB monoliths. Then remove the $\mathrm{H}_{2} \mathrm{O}$ solution through filtration.

3. Wash HOM-DDAB-L2 with deionized water until no L2 is eluted; then dry sample at $65-70{ }^{\circ} \mathrm{C}$ for $4 \mathrm{hr}$. Note: $0.07 \mathrm{mmol}$ of L2 ligand per gram of HOM scaffold was incorporated into HOM-DDAB ${ }^{42}$.

4. Clarify the formation mechanism of (MSA-2) based on the L2-DDAB-solid interaction.

\section{Batch Studies for Detecting Pd(II), Au(III), and Co(II) lons}

1. Immerse $20 \mathrm{mg}$ of wagon-wheel-shaped MSA-1, MSA-2, and MSA-3 in a mixture of $\mathrm{Pd}(\mathrm{II}), \mathrm{Au}(\mathrm{III})$, and $\mathrm{Co}$ (II) ions (ion concentration: 2 mg/L); adjust volume to $20 \mathrm{ml}$ and $\mathrm{pH}$ to appropriate $\mathrm{pH}$ value of 2,7 , and 5.2 , respectively.

2. Mechanically shake mixtures in a temperature-controlled water bath at $25^{\circ} \mathrm{C}$ for $45 \mathrm{~min}$ at a constant agitation speed of $300 \mathrm{rpm}$.

3. Filter MSAs through 25-mm filter paper; after equilibration, use visual color assessment and reflectance spectra measurements to determine ion concentrations.

4. Determine $\mathrm{Pd}(\mathrm{II}), \mathrm{Au}(\mathrm{III})$, and $\mathrm{Co}(\mathrm{II})$ target ion concentrations by comparing reflectance intensities of MSA-1, MSA-2, and MSA-3 at $\lambda_{\max } 384$, 486 , and $537 \mathrm{~nm}$, respectively, during the addition of unknown concentration of target samples with those of standard concentration of target samples.

5. Conduct other experiments using target $\mathrm{Pd}(\mathrm{II}), \mathrm{Au}(\mathrm{III})$, and $\mathrm{Co}(\mathrm{II})$ ion concentrations at the optimum pH value of 2,7 , and 5.2 , respectively, using UV-vis spectroscopy. The part per million (ppm, mg/L), part per billion (ppb, $\mu \mathrm{g} / \mathrm{L})$, and molar (mol/L) units are used to define the target ion concentration in solution.

\section{Method for Removing Pd(II), Au(III), and Co(II) lons}

1. Immerse $40 \mathrm{mg}$ of each wagon-wheel-shaped MSA in a mixture of specific $\mathrm{Pd}(\mathrm{II}), \mathrm{Au}(\mathrm{III})$, and $\mathrm{Co}(\mathrm{II})$ ion concentrations; adjust $\mathrm{pH}$ of mixture to specific values of 2, 7, and 5.2, respectively, in a volume of $20 \mathrm{ml}$, and stir mixture for $2 \mathrm{hr}$ at RT.

2. Filter solid MSAs and analyze filtrate by inductively coupled plasma mass spectroscopy (ICP-MS) ${ }^{28-30}$.

3. Calculate the Langmuir isotherm based on the following equation ${ }^{43}$ :

$\left.C_{\mathrm{e}} / q_{\mathrm{e}}=1 / K_{\mathrm{L}} q_{\mathrm{m}}\right)+\left(1 / q_{\mathrm{m}}\right) C_{\mathrm{e}}$

where $C_{\mathrm{e}}$ is target ion concentration, $q_{\mathrm{e}}$ is amount of target ion in equilibrated solution, $q_{m}\left(\mathrm{mg} \cdot \mathrm{g}^{-1}\right)$ is the amount of $\mathrm{Pd}(\mathrm{II}), \mathrm{Au}(\mathrm{III})$, or $\mathrm{Co}(\mathrm{II})$ ions removed to form the monolayer coverage, and $K_{\mathrm{L}}$ is the Langmuir adsorption equilibrium constant. For instance, the $q_{\mathrm{m}}$ data indicate the practical removal of the metal ions from the aqueous medium with high adsorption efficiencies (97\%-98\%). Moreover, $K_{\mathrm{L}}$ values are consistent with the adsorption/desorption rates, indicating fully reversible metal adsorption assays. 


\title{
6. Formation of Metal-to-ligand Binding Constants in Wagon-wheel-shaped MSAs
}

1. Determine stability constants ( $\left.\log K_{\mathrm{s}}\right)$ of $\left[\mathrm{Pd}-(\mathrm{L} 1)_{2}\right]$, [Au-(L2)], and [Co-(L3) $\left.)_{2}\right]$ complexes at pH 2, 7, and 5.2 , which can be expected to be around $5.8,4.9$, and 7.9 , respectively.

2. Calculate stability constants according to the following equation ${ }^{28-32}$ :

$\log K_{s}=\left([\mathrm{ML}]_{S} /[\mathrm{L}]_{\mathrm{S}}\right) \times[\mathrm{M}]$

where $[\mathrm{M}]$ is the concentration of free $\mathrm{Pd}(\mathrm{II}), \mathrm{Au}(\mathrm{III})$, or $\mathrm{Co}(\mathrm{II})$ ions in solution; [L] represents the concentration of free $L$ (i.e., $L$ not bound to the $\mathrm{Pd}(\mathrm{II}), \mathrm{Au}(\mathrm{III})$, or $\mathrm{Co}(\mathrm{II})$ ions); and subscript $\mathrm{S}$ refers to the total concentration of the $\mathrm{Pd}(\mathrm{II}), \mathrm{Au}(\mathrm{III})$, or $\mathrm{Co}(\mathrm{II})$ ions in the solid phase of the wagon-wheel-shaped MSA.

3. Determine limits of detection (LOD) of MSAs for $\mathrm{Pd}(\mathrm{II}), \mathrm{Au}(\mathrm{III})$, and $\mathrm{Co}(\mathrm{II})$ ions as follows:

$\mathrm{LOD}=3 \sigma / \Psi$

where $\sigma$ and $\Psi$ are the standard deviation and the slope of the calibration graph ${ }^{40-42}$.

\section{Selective-ion-extraction Experimental System}

\author{
NOTE: Ensure specific and strong metal-to-ligand binding as follows:
}

1. Adjust $\mathrm{pH}$ of extracted solution to 2,7 , and 5.2 for the $\mathrm{Pd}(\mathrm{II}), \mathrm{Au}(\mathrm{III})$, and $\mathrm{Co}(\mathrm{II})$ ions. Alter concentrations of interfering metal ions to $\leq 5$ times greater than the concentrations of the $\mathrm{Pd}(\mathrm{II}), \mathrm{Au}(\mathrm{III})$, and $\mathrm{Co}(\mathrm{II})$ target ions. Add a $2 \mathrm{ml}$ of complex-forming agent (e.g., 0.3-0.5 M citrate/ tartrate) to the extracted solution prior to the addition of target ions to restrain actively reacting $\mathrm{Cu}(\mathrm{II})$ ions.

\section{Real Extraction of Metals from Urban Mine}

1. Dissolve the $\mathrm{PCl}$ board in strong acids to get the metal ions in solution.

2. Add MSAs to the solution containing $\mathrm{Pd}(\mathrm{II}), \mathrm{Au}(\mathrm{III})$, and $\mathrm{Co}(\mathrm{II})$ ions to extract these ions into solid MSAs.

3. Filter solid MSAs and analyze filtrate by ICP-MS.

\section{Representative Results}

Periodic gyroidal cubic la3d monolithic scaffolds and wagon-wheel-shaped MSAs with large cylindrical open pores (up to $10 \mathrm{~nm}$ in diameter) were fabricated using pressure-assisted direct templating with a P123 copolymer microemulsion system. TEM micrographs of the MSAs show wagon-wheel-like channels organized in large domain sizes and in different orientational geometries in the gyroidal bicontinuous cubic la3d mesostructures (Figure 1). Although the L1, L2, and L3 probes were directly physisorbed into the monolithic scaffolds ( $\sim 80 \mathrm{mg}$ of probe per gram of scaffold), the MSAs provided control over potential leaching out of the ligands upon washing, sensing condition assays, and chemical treatment during regeneration/reuse cycles.

Wagon wheel shape-like pores featured the cubic la3d structures of the MSAs, as evidenced by the TEM images (Figure 1). The HRTEM micrographs recorded along the dominant facet in the [111] direction indicate the formation of cubic bi-continuous surface morphology ${ }^{37-39}$. Sixfold symmetric channels with different nano-sized interconnections in wagon wheel shape-like pores were characteristics the cubic la3d lattice structures of MSAs (Figure 1, center) ${ }^{44}$. Furthermore, the agreement in the unit cell lattice determining by TEM micrographs (22.5 nm) with the unit cell parameter determined by small-angle XRD $\left(a=d_{211} \sqrt{ } 6\right)$ indicates the formation of the cubic la3d MSA morphology.

The appearance of pores of various geometrical shapes in this six-fold orientation around each wagon wheel pattern is the key feature of controlled $\mathrm{Pd}(\mathrm{II}), \mathrm{Au}(\mathrm{III})$, and $\mathrm{Co}(\mathrm{II})$ ion diffusion, adsorption, and recovery. Figure 2B indicates that uniformly shaped pore geometries and textural properties of the cubic la3d MSA-1, MSA-2, and MSA-3 were retained (surface area $\left(S_{\mathrm{BET}}\right)$ of 560,520 , and $570 \mathrm{~m}^{2} / \mathrm{g}$; pore volume $\left(V_{\mathrm{p}}\right)$ of $1.03,0.98$, and $1.09 \mathrm{~cm}^{3} / \mathrm{g}$; and pore size $(D / \mathrm{nm})$ of $8.2,8.1$, and $8.2 \mathrm{~nm}$, respectively, as evidenced from $\mathrm{N}_{2}$ isotherm results). This retention of cubic la3d MSA structural integrity was used for the rational design of the MSAs, for which the Pd(II), Au(III), and Co(II) ions were detected with a fast response time, even at nanomolar concentrations (Figure 3-5). A sizeable number of organic moieties with potential functional active sites are strongly anchored onto the wagon wheel pore surfaces via $\mathrm{H}$-bonding and dispersive interactions with retention of the cubic la3d geometry, as evidenced by the Bragg reflection planes ( $h k l)$ (Figure 2A). The formation of stable organic-inorganic hybrid MSAs with suitable accommodation of L1, L2, and L3 into the wagon wheel pores might lead to no leaching of ligands during the metal ion sensing/capture/removal assays and reusability/recovery process.

The specificity and sensitivity of the wagon-wheel-shaped MSAs for the target $\mathrm{Pd}(\mathrm{II}), \mathrm{Au}(\mathrm{III})$, and $\mathrm{Co}(\mathrm{II})$ ions were controlled by adjusting the $\mathrm{pH}$ to 2,7 , and 5.2, respectively. These specific $\mathrm{pH}$ values are the most suitable for the selective, sensitive, and efficient monitoring and removal of metal ions using MSAs (Figure 6A). The quantification procedure for sensing/capturing $\mathrm{Pd}(\mathrm{II}), \mathrm{Au}(\mathrm{III})$, and $\mathrm{Co}(\mathrm{II})$ ions with MSA-1, MSA-2, and MSA-3 involved detecting changes in color intensity at color response times $\left(R_{\mathrm{t}}\right)$ of 2,3 , and $5 \mathrm{~min}$, respectively. To evaluate the sensitivities of the MSAs, color transitions in the reflectance spectra that could be detected by the human eye were carefully monitored over a wide range of metal ion concentrations (0-5,000 $\mu \mathrm{g} / \mathrm{L})$. Figures $6 \mathrm{~B}-\mathrm{D}$ show changes in color and reflectance intensity of MSA-1, MSA-2, and MSA-3 at $\lambda_{\max }$ 384,486 , and $537 \mathrm{~nm}$, respectively. These changes indicate metal-to-ligand binding events during the formation of the octahedral [Pd-(L1) 2 , square-planar [Au-(L2)], and octahedral [Co-(L3) $)_{2}$ complexes (the stability constants of these complexes are higher than those of competing-ion complexes; Figure 7). The reflectance spectral responses of the MSAs indicated the efficient detection/recognition of metals. In addition, Figure 6F shows that MSAs are very effective in removing and monitoring $\mathrm{Pd}(\mathrm{II}), \mathrm{Au}(\mathrm{III})$, and $\mathrm{Co}(\mathrm{II})$ ions from the urban mine and LIB solutions over a wide range of concentrations (from $\mu \mathrm{g} / \mathrm{L}$ to $\mathrm{mg} / \mathrm{L}$ ) and even at the low-concentration limits of $0.19,0.6$, and $0.51 \mu \mathrm{g} / \mathrm{L}$, respectively.

The ion-sensing/ion-removal efficiencies of the wagon-wheel-shaped MSAs toward Pd(II), Au(III), and Co(II) ions in the absence and in the presence of interfering ions were evaluated (Figure 7). Significant changes in the visible color patterns and reflectance spectra were evident, in most cases, upon addition of 1 to 18 competing ions [i.e., (G1) of $\mathrm{K}(\mathrm{I}), \mathrm{Na}(\mathrm{I}), \mathrm{Li}(\mathrm{I}), \mathrm{Ca}(\mathrm{II}), \mathrm{Fe}(\mathrm{III})$, and $\mathrm{Cu}(\mathrm{II}) ;(\mathrm{G} 2)$ of $\mathrm{Cd}(\mathrm{II}), \mathrm{Pb}(\mathrm{II}), \mathrm{Hg}(\mathrm{II})$, 
$\mathrm{Ni}(\mathrm{II}), \mathrm{Mn}(\mathrm{II}), \mathrm{Al}(\mathrm{III})$; and (G3) of $\mathrm{Bi}(\mathrm{III}), \mathrm{Zn}(\mathrm{II}), \mathrm{Dy}(\mathrm{III}), \mathrm{Er}(\mathrm{III}), \mathrm{Ho}(\mathrm{III})$, and $\mathrm{La}(\mathrm{III})]$ to the $\mathrm{Pd}(\mathrm{II}), \mathrm{Au}(\mathrm{III})$, and $\mathrm{Co}(\mathrm{II})$ ion systems, confirming selective removal and efficient monitoring of the target (T) ions. Low concentrations of $\mathrm{Ni}(\mathrm{II}), \mathrm{Cu}(\mathrm{II})$, and $\mathrm{Fe}(\mathrm{III})$ ions interfered, but interferences were eliminated by using $0.3-0.5 \mathrm{M}$ citrate/tartrate solution as a suppressing agent; no significant changes in the visible color patterns and reflectance spectra occurred upon addition of high concentrations of various cations at the optimal ion-sensing/capture conditions ( $\mathrm{pH} 2,7$, and $5.2,40 \mathrm{mg}$ of the MSAs, $20 \mathrm{ml}$ volume, $25^{\circ} \mathrm{C}$ ) (Figure 7). These findings indicated selective identification and capture of target ions in a wide range of real samples containing high concentrations of competing ions ${ }^{45,46}$

The reusability of the wagon-wheel-shaped MSAs was assessed by examining the reflectance spectra of the target ion sensing/capture assays and determining the uptake efficiency $(E \%)$ as a function of regeneration/reuse cycle. The recycling process was carried out by stripping the $\mathrm{Pd}(\mathrm{II}), \mathrm{Au}(\mathrm{III})$, and $\mathrm{Co}(\mathrm{II})$ ions from the MSA surfaces (i.e., decomplexation). Decomplexation was accomplished by treating the $\mathrm{Pd}(\mathrm{II})-, \mathrm{Au}(\mathrm{III})-$, and $\mathrm{Co}(\mathrm{II})$-MSAs with $0.1 \mathrm{M} \mathrm{HClO}_{4}, 0.1 \mathrm{M}$ thiourea in $1 \%$ concentrated $\mathrm{HCl}$, and $2 \mathrm{M} \mathrm{HCl}$, respectively. The decomplexation treatment was carried out repeatedly to completely remove the $\mathrm{Pd}(\mathrm{II}), \mathrm{Au}(\mathrm{III})$, and $\mathrm{Co}(\mathrm{II})$ ions from the MSA surfaces. UV-vis spectroscopy and ICP-MS were used to confirm that the MSA surfaces were free of metal (Figure 8). Uptake efficiencies for MSA-1, MSA-2, and MSA-3 were calculated as \% $\left(C_{A} / C_{0}\right)$, where $C_{A}$ is the target ion concentration uptake by solid MSAs and $C_{0}$ is the initial target ion concentration. Results indicated that the functionalities of the wagon-wheel-shaped MSAs were maintained over eight regeneration/reuse cycles ${ }^{46,47}$.

The recovery of $\mathrm{Pd}(\mathrm{II})$ and $\mathrm{Au}(\mathrm{III})$ from electronic scrap (i.e., $\mathrm{PCl}$ boards) and $\mathrm{Co}(\mathrm{II})$ from LIBs was carried out in several stages:

The first stage was the mechanical separation of grinded PCI board components.

The second stage included a pretreatment hydrometallurgical process, in which the $\mathrm{PCl}$ board chips (e-waste source) were leached in a mixture of $2 \mathrm{M} \mathrm{H}_{2} \mathrm{SO}_{4}$ and $0.2 \mathrm{M} \mathrm{H}_{2} \mathrm{O}_{2}$ at $90^{\circ} \mathrm{C}$ for $6 \mathrm{hr}$ to dissolve base metals ( $\mathrm{Cu}, \mathrm{Fe}, \mathrm{Ni}, \mathrm{Al}, \mathrm{Li}, \mathrm{Mn}, \mathrm{Co}$ and $\mathrm{Zn}$ ) and a suspension of partially dissolved plastic and $\mathrm{Pd}(\mathrm{II})$ and $\mathrm{Au}(\mathrm{III})$ ions ${ }^{8}$. After filtration of undissolved plastics, the residue was leached with a combined acid of $\mathrm{HCl}$ and $\mathrm{HNO}_{3}(3: 1)$ at $70{ }^{\circ} \mathrm{C}$ for $3 \mathrm{hr}$ to form a soluble solution of $\mathrm{Pd}(\mathrm{II}), \mathrm{Au}(\mathrm{III}), \mathrm{Ag}(\mathrm{I}), \mathrm{Fe}$ (III), $\mathrm{Sn}(\mathrm{IV})$ and $\mathrm{Al}(\mathrm{III})$ ions. The Fe (III), Sn(IV) and $\mathrm{Al}(\mathrm{III})$ ions precipitate by raising $\mathrm{pH}$ solution up to 4.5 using $2 \mathrm{M} \mathrm{NaOH}$ and filtered off. $\mathrm{AgCl}$ was precipitated using $\mathrm{NaCl}$ and filtered off (Figure 9). Additionally, the LIBs waste components were treated with $\mathrm{HNO}_{3}$, leading to a mixture of $\mathrm{Co}(\mathrm{II}), \mathrm{Ni}(\mathrm{II}), \mathrm{Mn}(\mathrm{II}), \mathrm{Li}(\mathrm{I}), \mathrm{Fe}(\mathrm{III})$, and $\mathrm{Al}(\mathrm{III})$ ions.

The third stage involved a series of batch experiments carried out under controlled experimental conditions. In these experiments, leach solutions were purified, $\mathrm{Pd}(\mathrm{II})$ and $\mathrm{Au}(\mathrm{III})$ ions were recovered from the electronic scrap solutions using MSA-1 and MSA-2 (see Figure 9), and Co(II) was recovered from the main products of the LIB solution using MSA-3 (Table 1). After removal, the filtrate was analyzed by ICP-MS.

In the fourth stage, the percentage uptakes of $\mathrm{Pd}(\mathrm{II})$ and $\mathrm{Au}(\mathrm{III})$ by MSA-1 and MSA-2 from a real urban mine composite mixture [0.119 mg/L $\mathrm{Pd}(\mathrm{II}), 0.35 \mathrm{mg} / \mathrm{L} \mathrm{Au}(\mathrm{III}), 0.23 \mathrm{mg} / \mathrm{L} \mathrm{Ag}(\mathrm{I}), 7.05 \mathrm{mg} / \mathrm{L} \mathrm{Cu}(\mathrm{II}), 5.78 \mathrm{mg} / \mathrm{L} \mathrm{Ni}(\mathrm{II}), 13.35 \mathrm{mg} / \mathrm{L} \mathrm{Fe}(\mathrm{III}), 7.09 \mathrm{mg} / \mathrm{L} \mathrm{Al}(\mathrm{III})]$ were determined. $\mathrm{MSA}-3 \mathrm{was}$ used to estimate the recovery of Co(II) ions from a real LIB composite mixture [1.75 mg/L Co(II), $420 \mathrm{mg} / \mathrm{L} \mathrm{Ni(II),} 350 \mathrm{mg} / \mathrm{L} \mathrm{Mn}$ (II), $370 \mathrm{mg} / \mathrm{L} \mathrm{Li}(\mathrm{I})$, $7 \mathrm{mg} / \mathrm{L} \mathrm{Fe}(\mathrm{III}), 1 \mathrm{mg} / \mathrm{L} \mathrm{Al}(\mathrm{III})]$. The efficiency of uptake of $\mathrm{Pd}(\mathrm{II}), \mathrm{Au}(\mathrm{III})$, and $\mathrm{Co}(\mathrm{II})$ ions by MSA-1, MSA-2, and MSA-3 was calculated as follows: $E \%=C_{\mathrm{A}} / C_{\mathrm{e}}=C_{0}-C_{\mathrm{e}} / C_{0}$, where $C_{\mathrm{A}}$ is the target ion concentration uptake by solid MSAs, and $C_{\mathrm{e}}$ and $C_{0}$ are the target ion concentrations in the equilibrated and initial solutions. Table 1 presents results for the real-sample study of the extraction of $\mathrm{Pd}(\mathrm{II}), \mathrm{Au}(\mathrm{III})$, and $\mathrm{Co}(\mathrm{II})$ using the MSAs; the percentage uptakes of $\mathrm{Pd}(\mathrm{II}), \mathrm{Au}(\mathrm{III})$, and $\mathrm{Co}(\mathrm{II})$ were approximately $79 \%, 68 \%$, and $66 \%$, respectively.

The fifth stage involved recovery experiments using stripping agents (Figure 3-5) to release $\mathrm{Pd}(\mathrm{II}), \mathrm{Au}(\mathrm{III})$, and Co(II) ions from the wagon-wheelshaped MSA surfaces. The recovery efficiency $(R \%)$ was calculated as follows: $R \%=C_{R} / C_{A}$, where $C_{R}$ is the target ion concentration released in solution by the stripping agent. ICP-MS analyses of the collected solutions indicated that $>>98 \%$ of the metal ions were released by simple chemical stripping (Table 1). This result indicates that ultra-trace levels of $\mathrm{Pd}(\mathrm{II}), \mathrm{Au}(\mathrm{III})$, and $\mathrm{Co}(\mathrm{II})$ ions were extracted from the urban mine by the MSAs. 


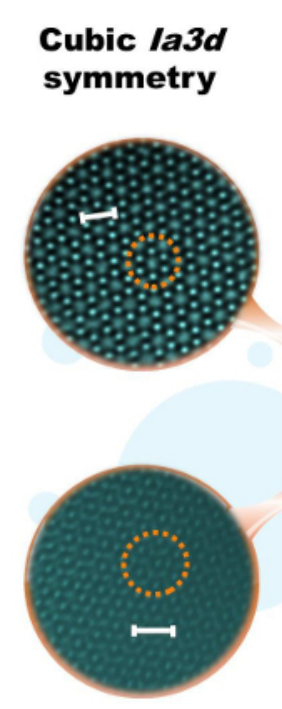

Bar=10.0 nm
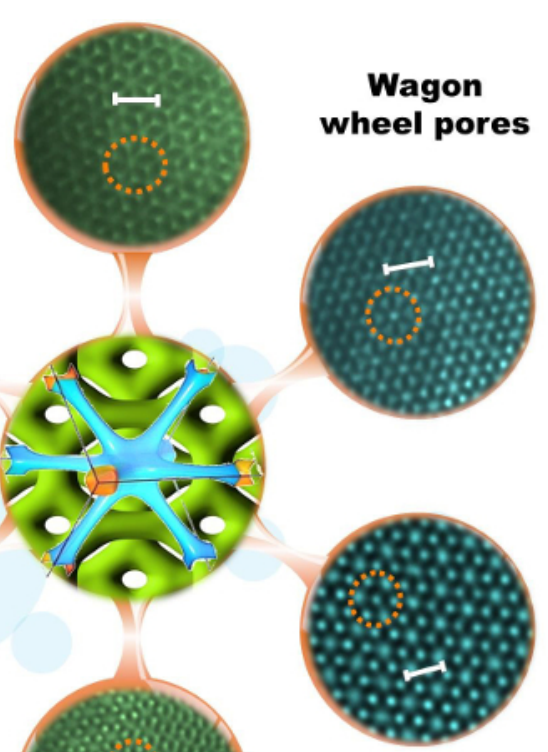

[111]

Figure 1. Investigation of wagon-wheel-shaped geometry. HRTEM micrographs of the wagon wheel pattern in the cubic la3d structures of the MSAs. Center: crystal shape.
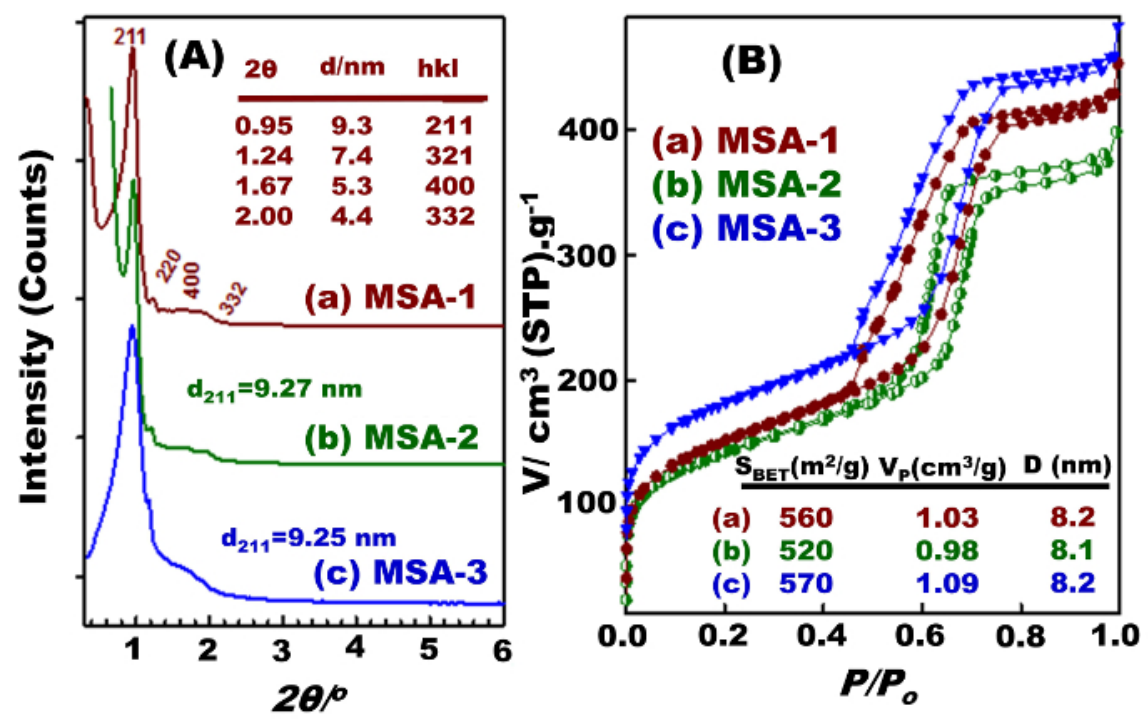

Figure 2. Determination of mesostructured crystal lattice and surface parameters of wagon-wheel-shaped pores. XRD patterns (A) and $\mathrm{N}_{2}$ adsorption/desorption isotherms (B) of the wagon-wheel-shaped, cubic la3d MSAs. 


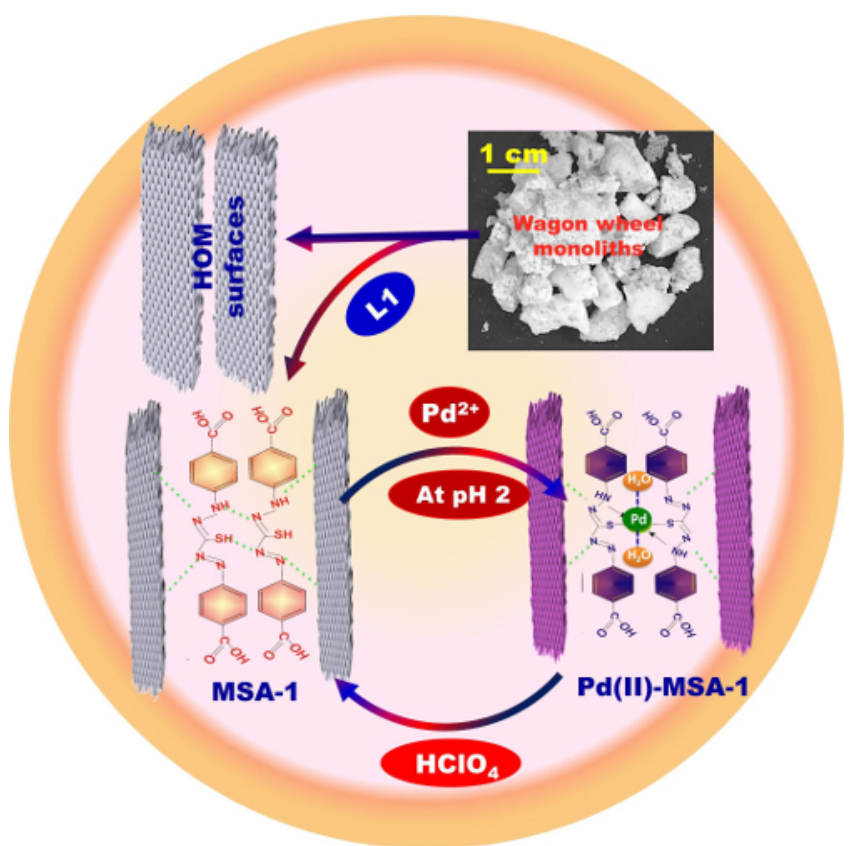

Figure 3. Systematic engineering of the MSA-1. Fabrication of Pd(II)-MSA-1 and Co(II)-MSA-3 via the pressure-assisted method.

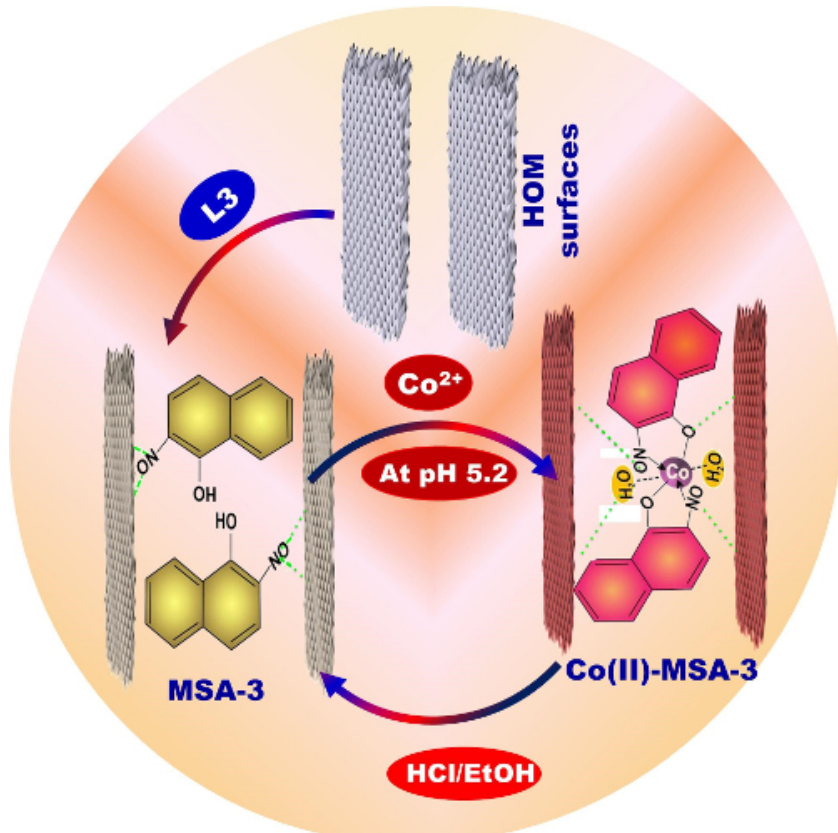

Figure 4. Systematic engineering of the MSA-3. Fabrication of $\mathrm{Co}(\mathrm{II})-\mathrm{MSA}-3$ via the pressure-assisted method. 


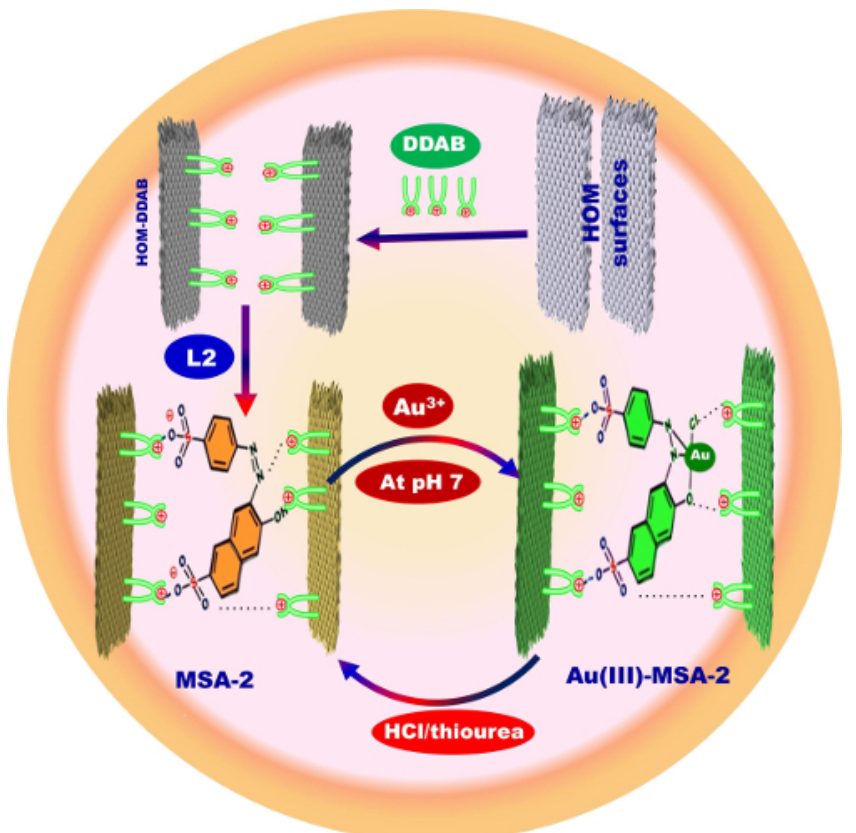

Figure 5. Systematic engineering of the MSA-2. Fabrication of Au(III)-MSA-2 via the building blocks protocol. 

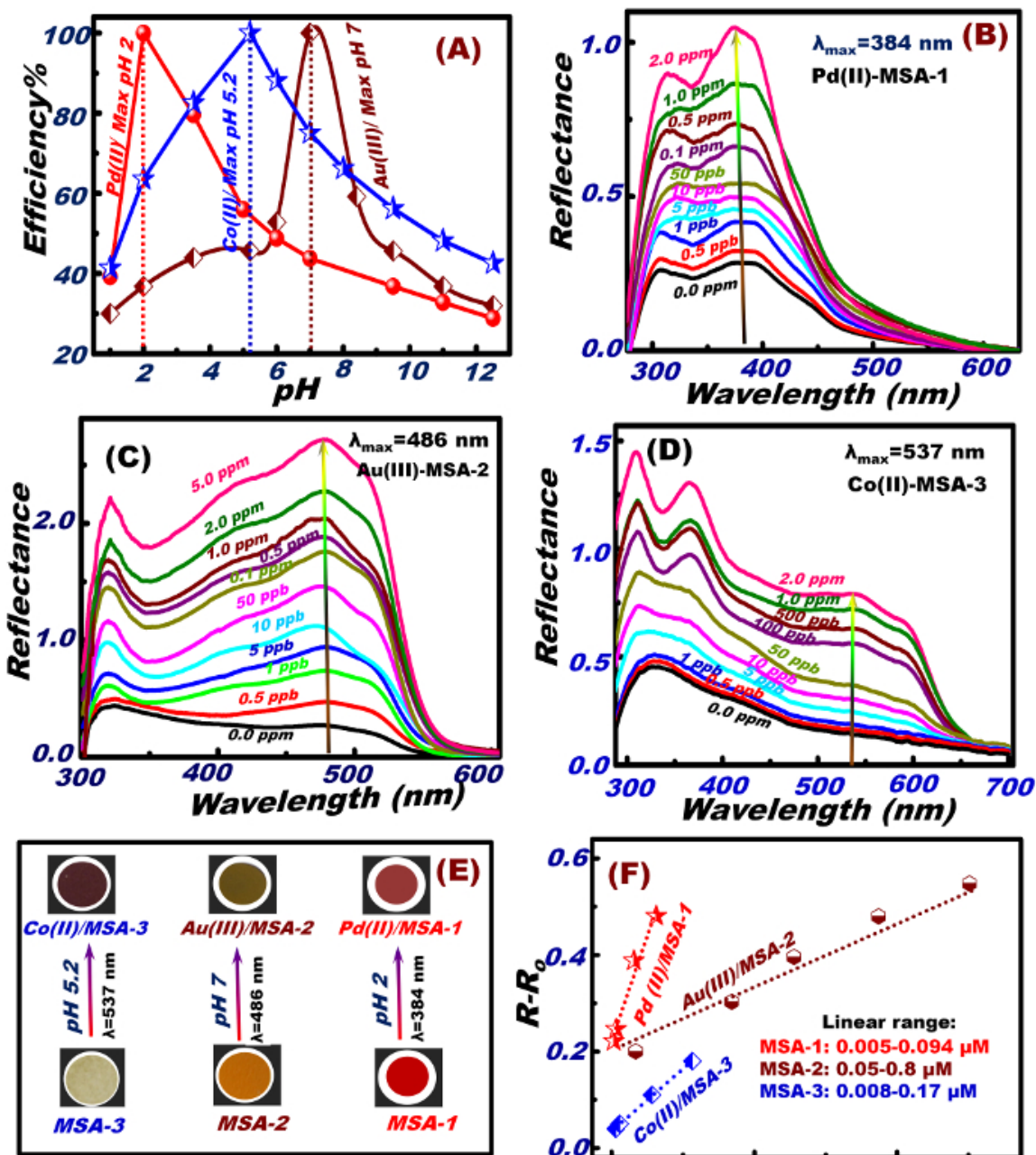

Color map of MSCs

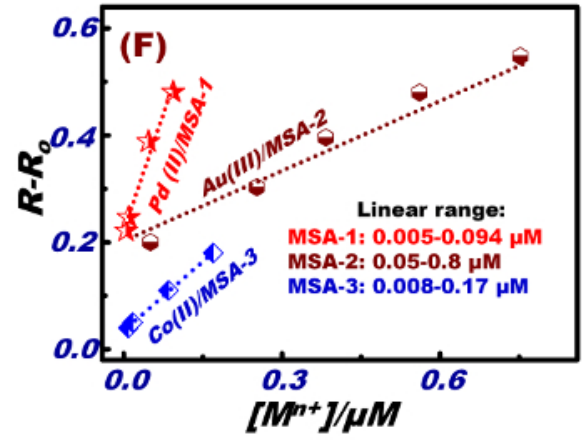

Figure 6. Controlled pH-dependent Pd(II), Au(III), and Co(II) ion-sensing systems. (A) pH-response profiles of wagon-wheel-shaped MSA-1, MSA-2, and MSA-3 during the sensing and removal assays of target $\mathrm{Pd}(\mathrm{II}), \mathrm{Au}(\mathrm{III})$, and $\mathrm{Co}(\mathrm{II})$ ions. The efficiency of the reflectance spectra was monitored as a function of $\mathrm{pH}$ at $\lambda_{\max }=384,486$, and $537 \mathrm{~nm}$, respectively. (B-D) Target ion concentration as a function of the reflectance spectra of MSA-1, MSA-2, and MSA-3, respectively. (E) Color maps for the MSAs with addition of $2 \mathrm{ppm} \mathrm{Pd}(\mathrm{II}), \mathrm{Au}(\mathrm{III})$, and Co(II). (F) Calibration plots of $\left(R-R_{0}\right)$ vs. [M $\mathrm{M}^{n+}$ ] for MSA-1, MSA-2, and MSA-3. Note: $R$ and $R_{0}$ represent the reflectance of the MSAs with and without the addition of target ions, respectively. 

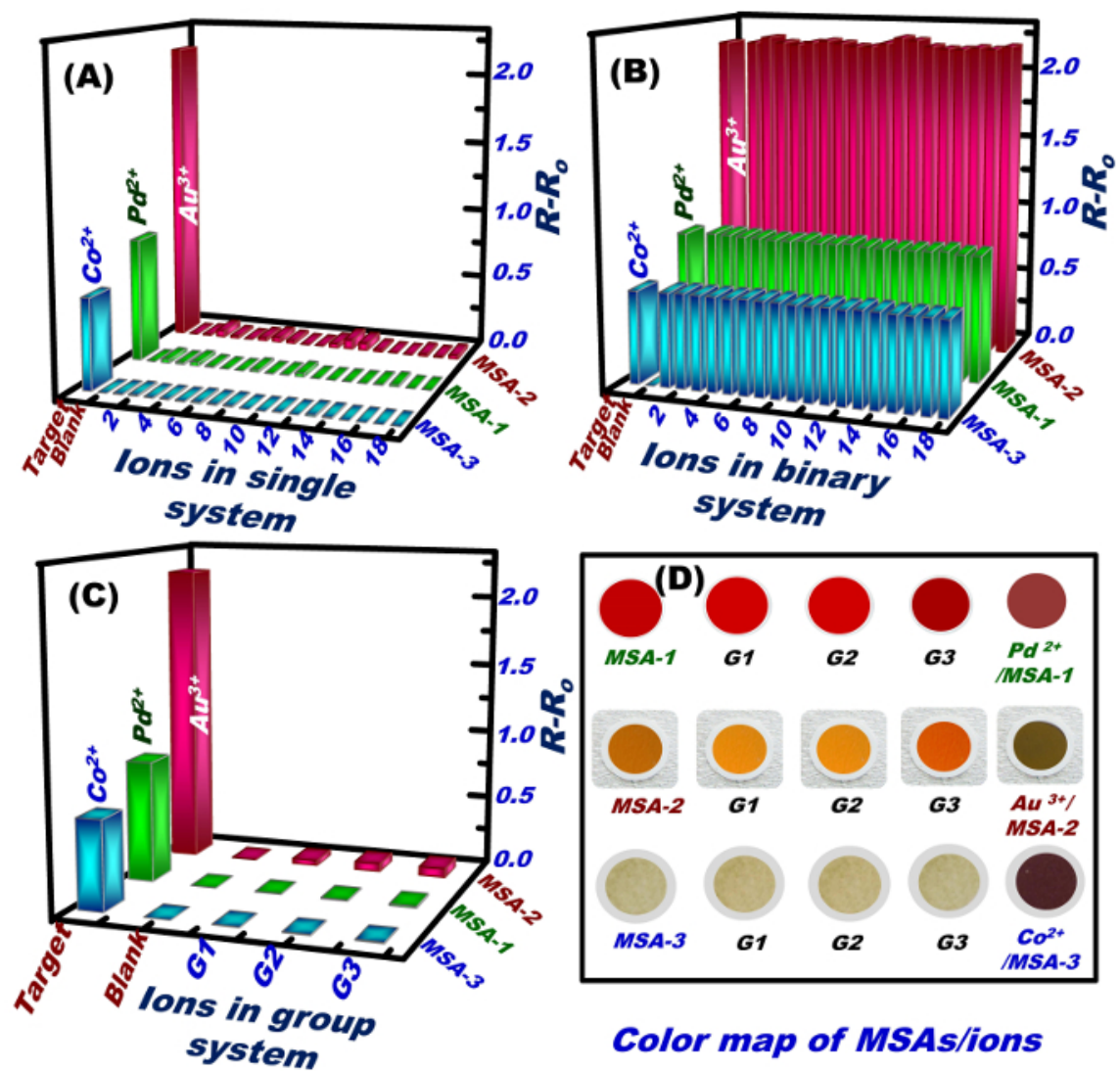

Figure 7. Study of the Pd(II), Au(III), and Co(II) ion-selective systems. (A-C) Selectivity of wagon-wheel-shaped MSA-1, MSA-2, and MSA-3 toward $\mathrm{Pd}(\mathrm{II})(2 \mathrm{mg} / \mathrm{L}), \mathrm{Au}(\mathrm{III})(1 \mathrm{mg} / \mathrm{L})$, and $\mathrm{Co}(\mathrm{II})(2 \mathrm{mg} / \mathrm{L})$ ion-sensing and ion-removal assays. (D) Sequential color response ofMSA-1, MSA-2, and MSA-3 (blank; i.e., metal-free assay) toward target $\mathrm{Pd}(\mathrm{II}), \mathrm{Au}(\mathrm{III})$, and $\mathrm{Co}(\mathrm{II})$ ions upon addition of interfering ions in single, binary, and groups of ions (G1-G3). 

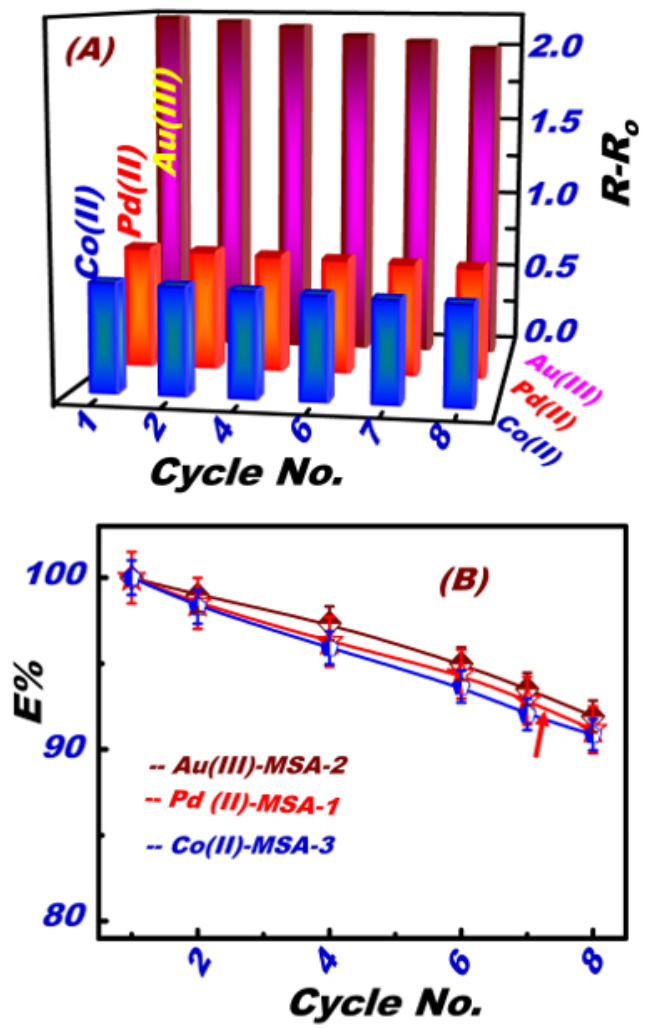

Figure 8. Reusability of wagon-wheel-shaped MSAs. (A) Evaluation of the wagon-wheel-shaped, optical sensing/removal assays of the target ions after eight regeneration/reuse cycles (target ion concentration: $2 \mathrm{mg} / \mathrm{L} ; \mathrm{pH}$ and signal response time values for MSA-1, MSA-2, and MSA-3: $\mathrm{pH}=2,7$, and $5.2, R_{\mathrm{t}}=2,3$, and $5 \mathrm{~min} ; t=25^{\circ} \mathrm{C}$ ). (B) Uptake efficiency vs. regeneration cycle number. 


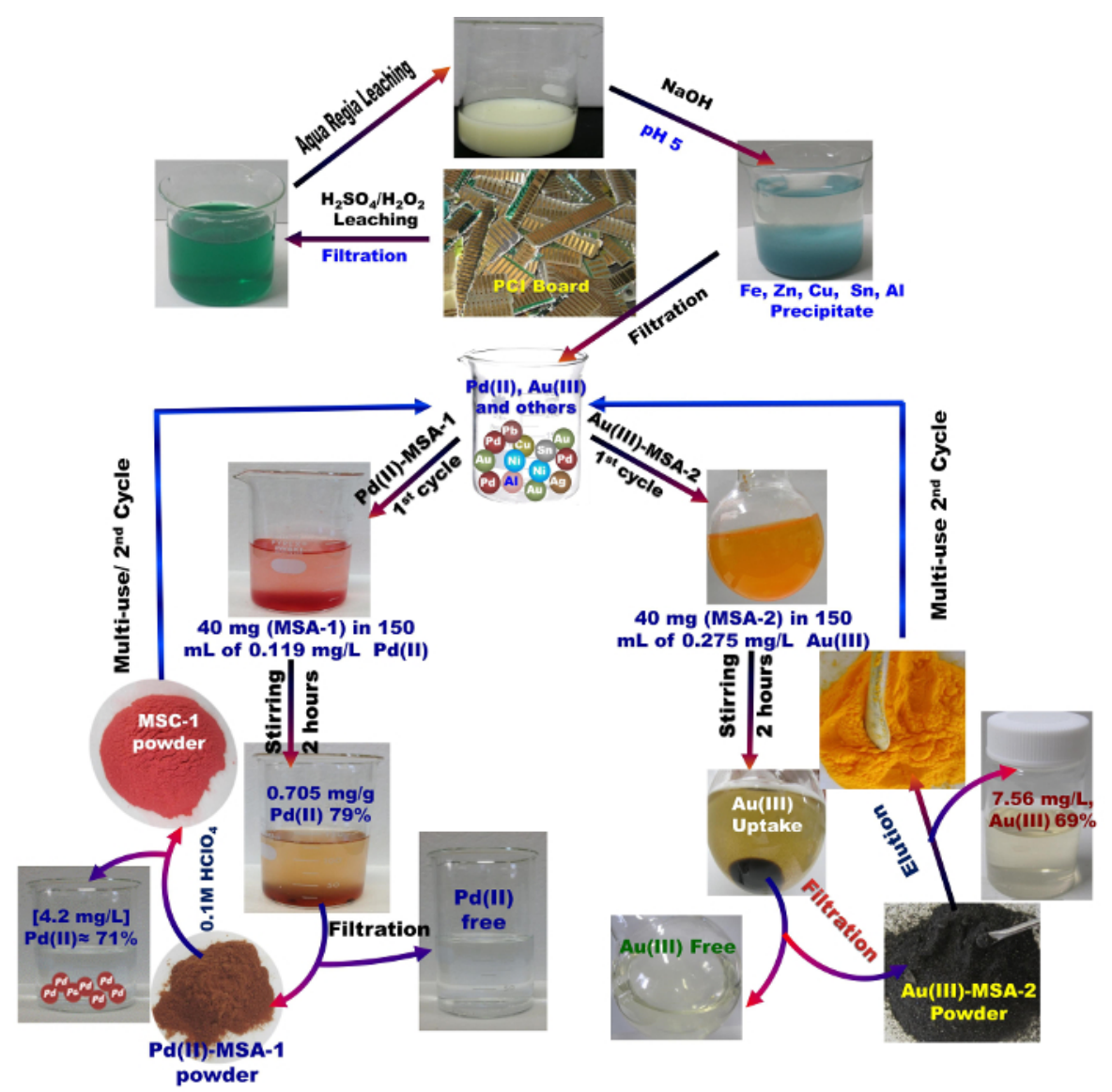

Figure 9. Real recovery of $\mathrm{Pd}(\mathrm{II})$ and $\mathrm{Au}(\mathrm{III})$ ions from electronic scrap solutions. Hydrometallurgical treatment of $\mathrm{PCI}$ boards and recovery of $\mathrm{Pd}(\mathrm{II})$ and $\mathrm{Au}(\mathrm{III})$ ions from electronic scrap solutions.

\begin{tabular}{|c|c|c|c|c|c|}
\hline $\begin{array}{l}\text { Target } \\
\text { ions }\end{array}$ & \begin{tabular}{|l|} 
Target ion- \\
determination
\end{tabular} & Target ions (mg/L) & Coexisted metal ions (mg/L) & E \% & $\begin{array}{l}\mathbf{R} \\
\%\end{array}$ \\
\hline \multirow[t]{3}{*}{$\mathrm{Pd}(\mathrm{II})$} & $\mathrm{C}_{0}$ & 0.119 & $\mathrm{Ag}(\mathrm{I}): 0.23, \mathrm{Au}(\mathrm{III}): 0.35, \mathrm{Al}(\mathrm{III}): 7.09, \mathrm{Ni}(\mathrm{II}): 5.78, \mathrm{Fe}(\mathrm{III}): 13.35, \mathrm{Cu}(\mathrm{II}): 7.05$ & \multirow[t]{3}{*}{79} & \multirow[t]{3}{*}{97} \\
\hline & $\overline{C_{e}}$ & 0.025 & $\mathrm{Ag}(\mathrm{I}): 0.225, \mathrm{Au}(\mathrm{III}): 0.351, \mathrm{Al}(\mathrm{III}): 7.11, \mathrm{Ni}(\mathrm{II}): 5.77, \mathrm{Fe}(\mathrm{III}): 13.32, \mathrm{Cu}(\mathrm{II}): 6.95$ & & \\
\hline & $\mathrm{C}_{\mathrm{R}}$ & 0.0913 & $\mathrm{Ag}(\mathrm{I}): 0.00, \mathrm{Au}(\mathrm{III}): 0.001, \mathrm{AI}(\mathrm{III}): 0.00, \mathrm{Ni}(\mathrm{II}): 0.002, \mathrm{Fe}(\mathrm{III}): 0.005, \mathrm{Cu}(\mathrm{II}): 0.009$ & & \\
\hline \multirow[t]{3}{*}{$\mathrm{Au}(\mathrm{III})$} & $\mathrm{C}_{0}$ & 0.35 & $\mathrm{Ag}(\mathrm{I}): 0.23, \mathrm{Pd}(\mathrm{II}): 0.119, \mathrm{Al}(\mathrm{III}): 7.09, \mathrm{Ni}(\mathrm{II}): 5.78, \mathrm{Fe}(\mathrm{III}): 13.35, \mathrm{Cu}(\mathrm{II}): 7.05$ & \multirow[t]{3}{*}{68} & \multirow[t]{3}{*}{98} \\
\hline & $\mathrm{C}_{\mathrm{e}}$ & 0.11 & $\mathrm{Ag}(\mathrm{I}): 0.231, \mathrm{Pd}(\mathrm{II}): 0.118, \mathrm{Al}(\mathrm{III}): 7.00, \mathrm{Ni}(\mathrm{II}): 5.66, \mathrm{Fe}(\mathrm{III}): 13.29, \mathrm{Cu}(\mathrm{II}): 6.92$ & & \\
\hline & $C_{R}$ & 0.235 & $\mathrm{Ag}(\mathrm{I}): 0.00, \mathrm{Pd}(\mathrm{III}): 0.002, \mathrm{AI}(\mathrm{III}): 0.00, \mathrm{Ni}(\mathrm{II}): 0.004, \mathrm{Fe}(\mathrm{III}): 0.003, \mathrm{Cu}(\mathrm{II}): 0.01$ & & \\
\hline \multirow[t]{3}{*}{$\mathrm{Co}(\mathrm{II})$} & $\mathrm{C}_{0}$ & 1.75 & $\mathrm{Ni}(\mathrm{II}): 420, \mathrm{Mn}(\mathrm{II}): 350, \mathrm{Li}(\mathrm{I}): 370, \mathrm{Fe}(\mathrm{III}): 2.00, \mathrm{Al}(\mathrm{III}): 0.40$ & \multirow[t]{3}{*}{66.3} & \multirow[t]{3}{*}{95} \\
\hline & $\mathrm{C}_{\mathrm{e}}$ & 0.59 & $\mathrm{Ni}(\mathrm{II}): 419.34, \mathrm{Mn}(\mathrm{II}): 350.06, \mathrm{Li}(\mathrm{I}): 370, \mathrm{Fe}(\mathrm{III}): 1.91, \mathrm{Al}(\mathrm{III}): 0.05$ & & \\
\hline & $\overline{C_{R}}$ & 1.15 & $\mathrm{Ni}(\mathrm{II}): 0.85, \mathrm{Mn}(\mathrm{II}): 0.00, \mathrm{Li}(\mathrm{I}): 0.00, \mathrm{Fe}(\mathrm{III}): 0.05, \mathrm{Al}(\mathrm{III}): 0.02$ & & \\
\hline
\end{tabular}

Table 1. Quantitative determination of metal ions in real samples. ICP-MS analytical data for the recovery of $\mathrm{Pd}(\mathrm{II}), \mathrm{Au}(\mathrm{III})$, and $\mathrm{Co}(\mathrm{II})$ ions in electronic scrap and LIB solutions.

\section{Discussion}

Worldwide demand is growing for a means to accurately and rapidly detect, selectively recognize, and recover $\mathrm{Pd}(\mathrm{II}), \mathrm{Au}(\mathrm{III})$, and $\mathrm{Co}(\mathrm{II})$ ions from electronic scrap and LIB solutions. To address this issue, wagon-wheel-shaped, optical MSAs for chemical detection/removal/extraction and recovery of these metal ions were developed.

In designing the MSAs, two key factors were considered as follows: (1) receptors and (2) immobilization/transducing scaffolds. Receptors are organic ligands responsible for the selectivity of the MSAs; scaffolds are responsible for the stability, reusability, and sensitivity of the MSAs. Because of their highly uniform channels, large surface areas, pore size distribution, and controllable wagon-wheel structure, which is commonly associated with the [111] projection of the cubic bicontinuous surface morphology (Figures 1 and 2), the MSA-based wagon wheel la3d mesostructure material scaffolds provided control over the potential demands of this detection/removal/extraction and recovery method 
as follows: (1) stability of ligand-embedding HOM solid (i.e., no leaching out of the ligands upon washing), (2) sensing condition assays, and (3) chemical treatment conditions during the regeneration/reuse cycles (i.e., after eight cycles); high ligand-surface coverage and dispersion; mechanical robustness; and efficient recovery processability from urban mine.

To fabricate the stable and robust MSAs design, the monofunctionalization of the wagon wheel inner pore surface or successive inclusion of different ligands (i.e., L1, L2, and L3; Figures 3-5) into the HOM scaffolds can be achieved by pressure-assisted co-condensation; the highorder hybrids MSA-1 and MSA-3 were obtained using L1 and L3, respectively. Controlled design of MSA-2 was based on the fine-tuned surface patterning of the mesoscopic wagon wheel scaffolding architectures. This was accomplished by using a dispersible active agent (DDAB) that led to the dense decoration of L2 signaling centers inside the wagon wheel pore cavities. With these MSA designs, metal ions can interact with organic moieties by noncovalent bonding (e.g., hydrogen bonding), metal coordination, hydrophobic forces, van der Waals forces, $\pi-\pi$ interactions, and electrostatic and/or electromagnetic effects (Figures 3-5). In sensing assays, nanoengineered MSAs can be triggered by a target $\mathrm{Pd}(\mathrm{II}), \mathrm{Au}(\mathrm{III})$,or $\mathrm{Co}(\mathrm{II})$ ion species and transduce measurable optical signals under synergistic $\mathrm{pH}$, reaction temperature, and contact time (response time) conditions, enabling the binding of the metals into a hydrophobic or hydrophilic ligand pocket to be mimicked. The developed MSAs not only removed $\mathrm{Pd}(\mathrm{II}), \mathrm{Au}(\mathrm{III})$, and $\mathrm{Co}(\mathrm{II})$ ions from complex environmental matrices but also provided a means for a simple visual colorimetric estimate of the metal ion concentration; UV-vis reflectance spectroscopy sensitively quantified metal ion concentration over a wide range of concentration (Figures 3-6). Thus, MSAs provide a simple and sensitive colorimetric-based solution to detect changes over a wide range of metal ion concentrations as well as a means for the sensitive quantification of the target ions, thereby avoiding the need for sophisticated instruments. Even at ultra-trace concentrations $(\leq 0.19 \mu \mathrm{g} / \mathrm{L})$, a signal change in the reflectance spectra of the sensors appeared during formation of the complexes (Figure 1).

In batch sensing/removal/extraction systems, a major advantage of the wagon-wheel-shaped MSAs is their selectivity toward target ions, thereby preventing hindrance from interfering competing ions. Figure 6 confirmed the selective removal and efficient monitoring of $\mathrm{Pd}(\mathrm{II})$, $\mathrm{Au}(\mathrm{III})$, and $\mathrm{Co}$ (II) ions by the optical MSAs. The negligible change in the reflectance signals of the MSAs in the presence of competing ions indicated that weak chelates were formed between competing metals and $\mathrm{L} 1, \mathrm{~L} 2$, and $\mathrm{L} 3$, specifically at $\mathrm{pH} 2,7$, and 5.2 , respectively. The selectivity of the MSAs can be ascribed to the formation of highly stable octahedral [Pd-(L1) $)_{2}$, square-planar [Au-(L2)], and octahedral [Co-(L3) $)_{2}$ complexes.

For judging the cost-effectiveness, recyclability and durability of wagon-wheel-shaped MSAs after repeated regeneration/reuse cycles were investigated. Figure 8 shows that the MSAs retained a high efficiency for detection/removal/extraction of $\mathrm{Pd}(\mathrm{II}), \mathrm{Au}(\mathrm{III})$, and Co(II) ions over repeated regeneration/reuse cycles, although overall efficiency decreased slightly after the sixth regeneration/reuse cycle. The stability of the cubic la3d mesostructure and the incorporation of L1, L2, and L3 into the ordered wagon-wheel-shaped pores (induced by strong $\mathrm{H}$-bonding and dispersive interactions) play significant roles in maintaining the functionality of the ion-sensing/capture system through several regeneration/ reuse cycles (see Figure 7).

Recovering $\mathrm{Pd}(\mathrm{II}), \mathrm{Au}(\mathrm{III})$, and $\mathrm{Co}(\mathrm{II})$ ions from the urban mine can help limit the environmental damage associated with mining these metals, especially with respect to the impact on land and climate. Using real urban mine samples, results have shown that the MSAs described herein can selectively recover Pd and Au from e-waste, and Co from discarded LIBs (Table 1 \& Figure 9), but practical, scalable process still remains challenge for the future applicability of the metal recovery from urban mine.

On the basis of the proposed management protocol, two key components play important roles in the enhanced metal ion accessibility, adsorption capacity, and recovery during the heterogeneous processes. First, the large surface-to-volume ratios and open cylindrical pores of the wagon wheel cubic la3d mesostructures (MSAs) promote orientational ligand assembly (as evidenced by the flexible interaction of $\mathrm{Pd}(\mathrm{II}), \mathrm{Au}(\mathrm{III})$, and Co(II) ions with L1, L2, and L3 and the high affinity of the metal-to-ligand binding events) (Figures 3-5). Second, the selective adsorption/ detection/extraction processes mainly depend on the structure of the chelating agent, the experimental conditions (particularly $\mathrm{pH}$ ), the composition of the ion system, the metal ion concentrations, and metal-to-ligand binding events. Although this protocol shows significant progress in the quality, and efficiency of the recovery methods, further efforts are required so that they can be used in other demanding applicability of environmental wastes, in which they enriched with high-doses of actively competitive metals such as $\mathrm{Cu}(\mathrm{II}), \mathrm{Fe}(\mathrm{III})$ and $\mathrm{Ni}(\mathrm{II})$ ions.

In conclusion, efficient, cost-effective, wagon-wheel-shaped MSAs have developed for recovering palladium, gold and cobalt metals from the urban mine. Results show evidence that MSAs will be useful in providing a route to a sustainable supply of gold, palladium, and cobalt to meet the needs of modern society.

\section{Disclosures}

The authors declare that they have no competing financial interests.

\section{Acknowledgements}

This work was supported by the Ministry of Education, Culture, Sports, Science \& Technology and the Ministry of Environment, Government of Japan.

\section{References}

1. Chung, S-W., \& Murakami-Suzuki, R. A Comparative study of e-waste recycling systems in Japan, South Korea and Taiwan from the EPR perspective: Implications for Developing Countries. Michikazu Kojima (ed.), Promoting 3Rs in developing countries-Lessons from the Japanese experience. Institute of Developing Economies, JETRO. 125-145, ISBN 978-4-258-58030-9 (2008).

2. Li, J., Lu, H., Guo, J., Xu, Z., \& Zhou, Y. Recycle technology for recovering resources and products from waste printed circuit boards, Environ. Sci. Technol. 41(6) 1995-2000 (2007).

3. Ammen, C. W. Recovery and Refining of Precious Metals. Springer, New York, 99-138 (1984). 
4. Hageluken, C. Recycling the platinum group metals: A European Perspective, Platinum Metals Rev. 56 (1), $29-35$ (2012).

5. Hall, W. J., \& Williams, P. T. Separation and recovery of materials from scrap printed circuit boards. Resour. Conserv. Recy. 51 (3), $691-709$ (2007).

6. Tuncuk, A., Stazi, V., Akcil, A., Yazici, E. Y., \& Deveci, H. Aqueous metal recovery techniques from e_scrap: Hydrometallurgy in recycling, Miner. Eng. 25 (1), 28-37 (2012).

7. Huang, K., Guo, J., \& Xu, Z. Recycling of waste printed circuit boards: A review of current technologies and treatment status in China, J. Hazard. Mater. 164 (2-3), 399-408 (2009).

8. Oh, C.J., Lee, S.O., Yang, H.S., Ha, T.J., \& Kim, M.J. Selective leaching of valuable metals from waste printed circuit boards. J. Air Waste Manage. 53 (7), 897-902 (2003).

9. Birloaga, I., De Michelis, I., Ferella, F., Buzatu, M., \& Vegliò, F. Study on the influence of various factors in the hydrometallurgical processing of waste printed circuit boards for copper and gold recovery. Waste Manage. 33 (4), 935-941 (2013).

10. Park, Y. J., \& Fray, D. J. Recovery of high purity precious metals from printed circuit boards. J. Hazard. Mater. 164 (2-3), $1152-1158$ (2009).

11. El-Safty, S. A., Shenashen, M. A., Ismael, M., Khairy, M., \& Awual, M. R. Optical mesosensors for monitoring and removal of ultra-trace concentration of $\mathrm{Zn}(\mathrm{II})$ and $\mathrm{Cu}(\mathrm{II})$ ions from water. Analyst. 137 (22), 5208-5214 (2012).

12. El-Safty, S. A., Shenashen, M.A., Ismael, M., Khairy, M., \& Awual, M. R. Mesoporous aluminosilica sensors for the visual removal and detection of Pd(II) and Cu(II) ions., Microporous Mesoporous Mater. 166, 195-205 (2013).

13. Khairy, M., El-Safty, S. A., \& Shenashen, M. A. Environmental remediation and monitoring of cadmium, TrAC Trends Anal. Chem. 62, 56-68 (2014).

14. Elci, L., Soylak, M., \& Buyuksekerci, E. B. Separation of gold, palladium and platinum from metallurgical samples using an amberlite XAD-7 resin column prior to their atomic absorption spectrometric determination. Anal. Sci. 19 (12), 1621-1624 (2003).

15. Medved, J., Bujdos, M., Matus, P., \& Kubova, J. Determination of trace amounts of gold in acid-attacked environmental samples by atomic absorption spectrometry with electrothermal atomization after preconcentration, Anal. Bioanal. Chem. 379 (1), 60-65 (2004).

16. Liu, P., Pu Q., \& Su, Z. Synthesis of silica gel immobilized thiourea and its application to the on-line preconcentration and separation of silver, gold and palladium, Analyst. 125 (1), 147-150 (2000).

17. El-Safty, S. A. Functionalized hexagonal mesoporous silica monoliths with hydrophobic azo- chromophore for enhanced Co(II) ion monitoring Adsorption. 15 (3), 227-239 (2009).

18. Zhao, J. M., Shen, X. Y., Deng, F. L., Wang, F. C., Wu, Y., \& Liu, H. Z. Synergistic extraction and separation of valuable metals from waste cathodic material of lithium ion batteries using Cyanex272 and PC-88A. Sep. Purf. Technol. 78 (3), 345-351 (2011).

19. Swain, B., Jeong, J., Lee, J. C., Lee, G. H., \& Sohn, J.S. Hydrometallurgical process for recovery of cobalt from waste cathodic active material generated during manufacturing of lithium ion batteries, J. Power Sources. 167 (2), 536-544 (2007).

20. El-Safty, S. A., Awual, M. R., Shenashen, M. A., Shahat, A. Simultaneous optical detection and extraction of cobalt(II) from lithium ion batteries using nanocollector monoliths, Sens. Actut. B Chem. 176, 1015-1025, (2013).

21. Barefoot, R. R., \& Van Loon, J. C. Recent advances in the determination of the platinum group elements and gold. Talanta. 49 (1), 1-14 (1999).

22. Gureva, R. F., \& Savvin, S. B. Spectrophotometric methods for determining noble metals, J. Anal. Chem. 57 (11), $980-996$ (2002).

23. Zhang, S., Pu, Q., Liu, P., Sun, Q., \& Su, Z. Synthesis of amidinothioureido-silica gel and its application to flame atomic absorption spectrometric determination of silver, gold and palladium with on-line preconcentration and separation, Anal. Chim. Acta. 452 (2), 223-230 (2002).

24. Hinds, M. Determination of gold, palladium and platinum in high purity silver by different solid sampling graphite furnace atomic absorption spectrometry methods, Spectrochim. Acta B. 48 (3), 435-445 (1993).

25. Elshehy, E. A., El-Safty, S. A., Shenashen, M. A., \& Khairy, M. Design and evaluation of optical mesocaptor for the detection/recovery of $\mathrm{Au}$ (III) from an urban mine, Sens. Actuat. B Chem. 203, 363-374 (2014).

26. Safavi A., \& Shams, E. Highly sensitive and selective measurements of cobalt by catalytic adsorptive cathodic stripping voltammetry. Talanta. $51(6), 1117-1123(2000)$.

27. Singh, A. K., Mehtab, S., Saxena, P. A novel potentiometric membrane sensor for determination of $\mathrm{Co}^{2+}$ based on 5-amino-3methylisothiazole Sens. Actut. B-Chem. 120 (2), 455-461 (2007).

28. Shenashen, M. A., Elshehy, E. A., El-Safty, S. A., \& Khairy, M. Visual monitoring and removal of divalent copper, cadmium, and mercury ions from water by using mesoporous cubic la3d aluminosilica sensors. Sep. Purif. Technol. 116, 73-86 (2013).

29. Shenashen, M. A., El-Safty, S. A., \& Elshehy, E. A. Architecture of optical sensor for recognition of multiple toxic metal ions from water. .J. Hazard. Mater. 260, 833-843 (2013).

30. Khairy, M., El-Safty, S. A., Shenashen M. A., \& Elshehy, E. A. Hierarchical inorganic-organic multi-shell nanospheres for intervention and treatment of lead-contaminated blood. Nanoscale. 5 (17), 7920-7927 (2013).

31. El-Safty, S. A., Khairy, M., \& Ismael, M. Visual detection and revisable supermicrostructure sensor systems of Cu(II) analytes. Sens. Actut. BChem. 166-167, 253-263 (2012).

32. Rampazzo, E., Brasola, E., Marcuz, S., Mancin, F., Tecilla, P., \& Tonellato, U. Surface modification of silica nanoparticles: a new strategy for the realization of self-organized fluorescence chemosensors, J. Mater. Chem. 15 (27-28), 2687-2696 (2005).

33. Han, W. S., Lee, H. Y., Jung, S.H., Lee, S. J., \& Jung, J. H. Silica-based chromogenic and fluorogenic hybrid chemosensor materials. Chem. Soc. Rev. 38 (7), 1904-1915 (2009).

34. Shenashen, M. A., El-Safty, S. A., Elshehy, E. A., \& Khairy, M. Hexagonal-prism-shaped optical sensor/captor for the optical recognition and sequestration of Pd" ions from urban mines, Eur. J. Inorg. Chem. 2015, 179-191 (2015).

35. Ros-Lis, J. V., Casasus, R., Comes, M., Coll, C., Marcos, M. D., Martinez-Manez, R., Sancenon, F., Soto, J., Amoros, P., El Haskouri, J., Garro, N., \& Rurack, K. A mesoporous 3D hybrid material with dual functionality for $\mathrm{Hg}^{2+}$ detection and adsorption. Chem. Eur. J. 14, 8267-8278 (2008).

36. Jung, J. H., Lee, J. H., \& Shinkai, S. Functionalized magnetic nanoparticles as chemosensors and adsorbents for toxic metal ions in environmental and biological fields. Chem. Soc. Rev. 40 (9), 4464-4474 (2011).

37. El-Safty, S. A., \& Hanaoka, T. Microemulsion liquid crystal templates for highly ordered three-dimensional mesoporous silica monoliths with controllable mesopore structures. Chem. Mater. 16 (9), 384-400 (2004).

38. El-Safty, S. A., \& Hanaoka, T. Fabrication of crystalline, highly ordered three-dimensional silica monoliths (HOM-n) with large, morphological mesopore structures. Adv. Mater. 15 (22), 1893-1899 (2003). 
39. El-Safty, S. A., \& Hanaoka, T. Monolithic nanostructured silicate family templated by lyotropic liquid-crystalline nonionic surfactant mesophases. Chem. Mater. 15 (22), 2892-2902 (2003).

40. Balaji, T., El-Safty, S. A., Hanaoka, T., Matsunaga, H., Mizukami, F. Optical sensors-based nanostructured cage materials for detection of toxic metal ions. Angew. Chem. Int. Ed. 45 (43), 7202-7208 (2006).

41. Huang, J., Gao, X., Jia, J., Kim, J-K., \& Li, Z. Graphene oxide-based amplified fluorescent biosensor for $\mathrm{Hg}^{2+}$ detection through hybridization chain reactions, Anal. Chem. 86 (6), 3209-3215 (2014).

42. El-Safty, S. A., Shenashen, M. A., Ismael M., \& Khairy, M. Mesocylindrical aluminosilica monolith biocaptors for size-selective macromolecule cargos. Adv. Funct. Mater. 22 (14), 3013-3021 (2012).

43. Kreno, L. E., Leong, K., Farha, O. K., Allendorf, M., Van Duyne, R. P., \& Hupp, J. T. Metal Organic Framework Materials as Chemical Sensors, Chem. Rev. 112 (3), 1105-1125 (2012).

44. El-Safty, S. A., Hanaoka, T., \& Mizukami, F. Large scale design of cubic la3d mesoporous silica monoliths with high order, controlled pores, and hydrothermal stability. Adv. Mater. 17 (1), 47-53 (2005).

45. El-Safty S. A., \& Shenashen, M. A. Mercury-ion optical sensors. Trends Anal. Chem. 38 (1), 98-115 (2012).

46. El-Safty, S. A., Shenashen, M. A., \& Ismail, A. A. A multi-pH-dependent, single optical mesosensor/captor design for toxic metals. Chem. Commun. 48 (77), 9652-9654 (2012).

47. Shenashen, M. A., El-Safty, S. A., \& Elshehy, E. A. Monolithic scaffolds for highly selective ion sensing/removal of $\mathrm{Co}(\mathrm{II}), \mathrm{Cu}(\mathrm{II})$, and $\mathrm{Cd}(\mathrm{II})$ ions in water. Analyst. 139(24), 6393-6405 (2014). 